\title{
La actitud anti-modernista del crítico «Clarín»
}

JoSÉ MARÍA MARTÍNEZ CACHERO

Universidad de Oviedo

¿Tendría razón Ramiro de Maeztu, espectador atento de nuestra república literaria y nada afecto al Modernismo ${ }^{1}$, cuando en octubre de 1899 reprochaba a «los pontífices de la crítica», en general, y a «Clarín», muy particularmente, no haber prestado la debida atención a «la juventud intelectual», al «movimiento intelectual» de esa juventud en América y en España? Aquello pedía amplia comprensión y eficaz estímulo, y pudo ser encauzado provechosamente con bien poco esfuerzo, pero se quiso, por el contrario, atajar zahiriéndolo y, con método tan reprobable, nada se consiguió. «Pudieron nuestros críticos, Clarín es-

1 En mi «Nota sobre el Modernismo. (Un artículo de José Nogales y otro de Ramiro de Maeztu)» (Archivum, Oviedo, I, 1951, pp. 161-165), ofrezco y comento el texto de «Poesía modernista», artículo de Maeztu que vio la luz en Los Lunes de El Imparcial (Madrid, 14-X-1901).

Otras referencias antimodernistas de Maeztu ofrece Ignacio M. Zuleta, «El Modernismo hispanoamericano y Ramiro de Maeztu» (Cuadernos para investigación de la literatura hispánica, Madrid, n. ${ }^{\circ} 2-3,1980$, pp. 327-339). 
pecialmente, encauzar este movimiento, españolizarlo, infundiéndole un ideal concomitante [...] No quiso ver Clarín ese espíritu nuevo [...] que iba a deshacer los viejos moldes del idioma castellano... Era más cómodo y productivo mantener en su integridad el dogma del casticismo. ¡Y ahí está esa literatura, a la vez española y exótica, que nos avergüenza con sus brios juveniles [...]» ${ }^{2}$.

Pero este "Clarín» anti-modernista por aferrado tercamente a principios casticistas fue, antes de 1899 , mucho más atento y comprensivo con las novedades literarias, cuya existencia estimaba indispensable para animar un panorama de postración y anquilosamiento estéticos; ciertos textos y determinadas actitudes hablan elocuentemente al respecto.

Ejemplo de ello puede ser el extenso trabajo sobre Baudelaire y Les fleurs du mal: siete artículos de $1887^{3}$, posteriormente recogidos por «Clarín» en el volumen Mezclilla (crítica y sátira) ${ }^{4}$. Lo que el crítico ofrece ahora son las impresiones de su segunda lectura del libro, acaso motivadas por el disgusto que le produjo el negativo artículo de Brunetière en la Revue des Deux Mondes. ¿Por qué leer y comentar con «esa prevención retórica, fría, maligna»?, ¿por qué cerrar «ojos y oídos a los señuelos secretos que en sus versos [los de Baudelaire en Les fleurs...] gritan y hacen gestos para que pueda comprendérsele»?, que es cabalmente el modo de proceder adoptado por el crítico francés. No quiere decir esto que «Clarín» considere a Baudelaire como un genio o poco menos - «yo [advierte] no tengo a Baudelaire por un poeta de primer orden»-, ni que Alas milite entre sus rendidos incondicionales - «ni su estilo, ni sús ideas, ni la estructura de sus versos siquiera, me son simpáticos $)-$. Pero ¿cómo no reconocer y elogiar tantos poemas

2 Ramiro de Maeztu, «Clarín, Madrid Cómico and C. ${ }^{\circ}$ Limited», (Revista Nueva, Madrid, II, 2. ${ }^{a}$ serie, n. ${ }^{\circ} 25,15-X-1899$, pp. 49-54).

3 Publicados en La Ilustración Ibérica, Barcelona, núms. 238, 241, 246, 247, 251, 253 y 256 (julio a noviembre 1887).

4 . Madrid, 1889, pp. 55-98.

Juan Ramón Jiménez (El Modernismo. Notas de un curso (1953), pp. 234-235, México, Aguilar, 1962) celebra este trabajo de "Clarín" con las siguientes palabras: «El ensayo famoso de Clarín, en ese momento, sobre Baudelaire, importante ensayo, no solamente por la calidad del escritor (Clarín era uno de los grandes prosistas españoles de esa época), sino porque se hablara en España ya de Baudelaire en aquel momento; es decir, todavía a fines del siglo XIX, cuando en Francia casi nadie hablaba de Baudelaire más que para hablar mal de él. Brunetière hablaba muy mal; Anatole France hablaba mal de Baudelaire; pues, en cambio, Clarín habló bien. Yo recuerdo que cuando leí ese artículo de Clarín, al momento pedí Baudelaire, que me mandaran las obras de Baudelaire a mi librería de Madrid $[\ldots] »$ 
de Les fleurs... que son «cuadros breves, sobrios y vigorosos»?, ¿cómo no valorar su condición de poeta que «siempre escribe para el alma, y para el alma espiritual», en lo que excede a tantos colegas contemporáneos, de su país y de otros países?; por último (y siguiendo la lucubración «clariniana»), ¿cómo no agradecer al poeta de Les fleurs... que tras la lectura de su libro, uno, mero lector que ya no crítico, posea la certidumbre de que «ha estado comunicando poéticamente con un espíritu elevado, con una conciencia de las escogidas»?

Nuestro crítico ha querido ponerse (y ha acertado al hacerlo) en el lugar de Baudelaire, cosa que no llevaron a cabo, entre sus colegas franceses, ni Brunetière ni Anatole France, ni en España don Juan Valera, quien «hablaba con burla y tedio de la pose de Baudelaire» ${ }^{5}$. Distingue reiteradamente (a lo largo del séptimo y último de sus artículos) entre Baudelaire y la turbamulta de los simbolistas, donde no debe ser incluido y de cuyos «extravíos» no resulta responsable. Deslindados así los respectivos terrenos, carga «Clarín» contra los presuntos innovadores parisienses, que pertenecen a la categoría de «el pobre diablo [no a la de "el escritor verdadero"'] que busca un pedazo de pan dando dos vueltas por los aires», y así «llegan al absurdo grotesco». Lucen los tales específicas dotes «para la incoherencia lógica» y consiguen que la llamada retórica nueva se ofrezca con apariencia de «charada, logogrifo y laberinto poético». Para ellos - «tontos y necios que se meten a poeta»- no sirve ponerse en su lugar, ya que (asevera «Clarín»), «el mejor trato es el de cuerda». Sí y no, por tanto, de nuestro crítico ante las novedades poéticas de Francia.

Conviene echar mano ahora de algunos textos «clarinianos» datados entre 1887 y 1892 , todos ellos relativos a la pertinencia, inclusive necesidad, de una sustancial renovación en nuestra poesía, tarea por la que «Clarín» mostró primeramente cierto interés que, con el paso de no demasiados años y ante las experiencias producidas, se atenuaría considerablemente hasta convertirse en hostilidad y rechazo.

El primer texto de este breve florilegio es de 1887 y se contiene en Apolo en Pafos, uno de los más ricos «Folletos literarios» de Alas, número tres de la serie. Conversa el autor con la musa Erato, a la que expone la situación actual de la poesía en España, que pasa por un mal momento para el que no se vislumbra salida; "Clarín» pregunta a su ocasional pareja: «¿Ves ese pesimismo, ese trascendentalismo naturalista, ese orientalismo panteístico o nihilista, todo lo que antes recorda-

5 P. 73 de Mezclilla. 
bas tú como contrario a tus aspiraciones, pero reconociendo que eran fuentes de poesía a su modo?», y contesta seguidamente: «Pues todo ello lo diera yo por bien venido a España, a reserva de no tomarlo para mí, personalmente, y con gusto vería aquí extravíos de un Richepin, satanismos de un Baudelaire, preciosismos psicológicos de un Bourget, quietismos de un Amiel y hasta la procesión caótica de simbolistas y decadentes; porque en todo eso, entre cien errores, amaneramientos y extravíos, hay vida, fuerza, cierta sinceridad, y sobre todo un pensamiento siempre alerta... ${ }^{6}$. (Nuestro crítico enumera mezcladamente y coloca casi en el mismo renglón a Baudelaire y a los simbolistas, para los cuales hay en el texto - que data del mismo año de los artículos sobre Baudelaire- alguna aceptación en cuanto que lo hecho por ellos es señal de vida y de fuerza.)

Los textos segundo y tercero (más breves que el anterior) datan de 1890 y pertenecen a sendas colaboraciones periodísticas. Insiste uno de ellos en el estado de anquilosis por el que atravesaba a la sazón nuestra poesía, dado que «todo se reduce a escribir como Campoamor, o como Bécquer, o como Núñez de Arce» ${ }^{7}$. («Clarín» subraya intencionadamente el cómo que precede a cada uno de esos tres indisputados modelos). En el otro texto ${ }^{8}$ es aprovechada la ocasión -comentario al libro De los quince a los treinta, obra del poeta Ricardo Gil- para aludir de pasada a «la revolución rítmica que tanto necesitamos» y en la que andaba metido, con el conocimiento y beneplácito de nuestro crítico, Salvador Rueda.

Corresponden a 1892 los textos cuarto y quinto de esta recogida, relacionados ambos con el escritor guatemalteco Enrique Gómez Carrillo, un modernista aparisiensado con el que Alas tuvo buena amistad y cuyo libro Almas y cerebros prologó en 1898. Uno de esos textos (párrafo de una carta de «Clarín» a Gómez Carrillo) muestra la retirada del remitente, desilusionado y hasta alarmado por los usos y abusos renovadores, ya que el interés que pudo sentir tiempo atrás se ha extinguido totalmente: «Hace algunos años [...], yo seguía con atención e interés la vida inquieta de la literatura de los jóvenes, según era en París y sus muchas sucursales. Hoy confieso que he dejado, por hastío, de seguir tales cambios. Me ha aburrido la poca formalidad, y me he cansa-

6 P. 85 de Apolo en Pafos.

7 Artículo La crítica y la poesía en España (enero 1890), recogido en el volumen Ensayos y revistas (Madrid, 1892, p. 270).

8 «Palique» en Madrid Cómico, n. ${ }^{\circ} 399,11-\mathrm{X}-1890$. 
do de esperar cosas de mucha substancia, que no llegan» ${ }^{9}$. En el comentario «clariniano» al libro Esquisses de su amigo, que era un conjunto de semblanzas de los escritores más de moda en París a finales de siglo, se califica de «noble» la tarea divulgadora e informativa cumplida por tan brillante cronista, pero se apunta un serio peligro, ya que «¿no estará expuesta a favorecer esa disolución de lo español, de lo castizo, de lo nuestro? Sí lo está y su propaganda, qụe desde el punto de vista de la noticia, de la información, es excelente, necesita correctivo por otro lado" ${ }^{10}$. Sí y no de nuestro crítico, para quien la extranjería galicana y la consiguiente descastización (valga la palabra) constituyen motivo de rechazo, y en ello coincide con bastantes anti-modernistas coetáneos ${ }^{11}$.

El anti-Modernismo que profesó Leopoldo Alas es un capítulo literario (personal a veces) que se inscribe en un conjunto más amplio, a saber: sus relaciones con la joven literatura española en el momento finisecular. Se ha dicho en alguna ocasión que nuestro crítico fue muy comprensivo y tolerante, muy elogioso también, 'con los consagrados - «soy de los que creen en las jerarquías invisibles, a respetarlas me consagro [...]» ${ }^{12}-$, en tanto que no atendía debidamente a los recién llegados - se recuerda siempre el caso de Unamuno y de su novela Paz en la guerra, aunque también ha de recordarse el estímulo prestado a José Martínez Ruiz ${ }^{13}$-; «tal vez no dedicó a los jóvenes la atención que merecían [...]. Ni al propio Unamuno, ni a Blasco Ibáñez, ni a Ganivet, los comentó con aquella penetrante y generosa mirada que

9 Enrique Gómez Carrillo, La miseria de Madrid..., p. 121. (Madrid, Mundo Latino, 1923).

10 Artículo en El Imparcial (Madrid, un n. ${ }^{\circ}$ de 1892).

11 He documentado semejante hostilidad entre escritores españoles en mis trabajos: «Algunas referencias sobre el anti-Modernismo español» (Archivum, Oviedo, III, 1953, pp. 311-333), «El anti-Modernismo del poeta Emilio Ferrari» (Idem, IV, 1954, pp. 368-384), «Más referencias sobre el anti-Modernismo español» (Idem, V, 1955, pp. 131-135) y «Salvador Rueda y el Modernismo» (Boletín de la Biblioteca de Menéndez Pelayo, Santander, XXXIV, 1958, pp. 41-61).

Por su parte, Jorge Campos («Cuando Juan Ramón empezaba. La crítica burlesca contra el Modernismo», Insula, Madrid, n. ${ }^{0} 128-129$, VII-VIII 1957, pp. 9 y 21) y Carlos Lozano («Parodia y sátira en el Modernismo», Cuadernos Americanos, México, CLXI, 1965, n. ${ }^{\circ} 4$, pp. 180-200) han exhumado curiosos testimonios.

12 Folleto literario IV, Mis plagios..., p. 131 (Madrid, 1888).

13 Puede consultarse al respecto mi artículo «Clarín y Azorín. (Una amistad y un fervor)" (Archivum, Oviedo, III, 1953, pp. 159-180); posteriormente se ha ocupado de este asunto Antonio Ramos Gascón, «Relaciones Clarín-Martínez Ruiz, 18971900) (Hispanic Review, XLII, 1974, n. ${ }^{\circ} 4$, pp. 413-426). 
hubiéramos ${ }^{14}$ querido encontrar siempre en él». ¿Estaba «Clarín» en contra de los jóvenes? Cabría pensar que así era cuando al reaparecer bajo su dirección (otoño de 1899) el semanario Madrid Cómico afirmaba, en una como declaración previa ${ }^{15}$, que éste, cuya muerte ya contaban «ciertos apreciables efebos de las malas lecturas azules», se robustecería en adelante con «sangre vieja», a saber: las colaboraciones de escritores como López Silva, Mariano de Cavia, Ramos Carrión, Vitạl Aza, Eusebio Blasco, Valera o Galdós. Pero tampoco debe ser olvidado aquel lema suyo del mismo año 99: «Amo a la juventud; pero no la adulo» ${ }^{16}$.

Repasando ahora los textos «clarinianos» en que se contiene particular referencia a escritores españoles más y menos próximos al movimiento modernista -o coincidentes con él cronológicamente, o, de algún modo, sus anticipadores, o bien modernistas plenos-, encontraremos palabras y reacciones que sirven para precisar la actitud de su autor al respecto que nos ocupa.

Del año 1900 (en sendos «paliques» de Madrid Cómico) datan los elogios que tributa «Clarín» a dos poetas jóvenes pero no apuntados al Modernismo más en boga y esto - su juventud y su modernidad original- parece ser lo que satisface al crítico, complacido en presentatarlos y utilizarlos como arma arrojadiza frente a tantos colegas extraviados. Se trata del almeriense Francisco Aquino Cabrera (nacido en 1869) y de su libro Sensaciones (1900), que «Clarín» estima como la obra de un poeta «sin nada pentélico, ni pasmos, ni lirios; sin necesidad de teñir de $a z u l$, como una mala planchadora, los versos», tras lo cual elogia más directamente a quien «nos hace sentir y gozar con la música de rimas muy armoniosas [...] ${ }^{17}$; se trata, asimismo, del catalán Eduardo Marquina (nacido en 1879) y de su libro Odas (1900), que es para el crítico la obra de un poeta «nuevo, poeta de veras», con abundancia de ideas y de imágenes, bien al contrario (y aquí el arma arrojadiza) «de lo que puede notarse en muchos que en España cultivan el verso por el verso [y que] no tienen nada que decir [...]» ${ }^{18}$. Pero «Clarín» advierte en el verso libre de Marquina, vehículo de una poesía no poco discursiva, falta o escasez de «facultades musicales» 0 , con otras

14 Ricardo Gullón, «Clarín, crítico literario», pp. 46-47 (Universidad, Zaragoza, $1949,{ }^{\circ}$ 3).

15 «La reconquista», Madrid Cómico, n, ${ }^{\circ}$ del 7-X-1899.

16 De un «palique» en La vida literaria (Madrid, 6-VII-1899).

17 En Madrid Cómico, 24-III-1900.

18 En Madrid Cómico, 10-II-1900. 
palabras, «todo eso del ritmo y de la rima» que si no es ingrediente único y exclusivo, como parecen mantener algunos modernistas, tampoco debe despreciarse como mero "requisito de la reaccionaria Poética». («De la Musique», sí, diríase que piensa verlainianamente Leopoldo Alas, pero nunca «avant toute chose»).

Dos poemas del murciano Vicente Medina (nacido en 1866), los titulados Cansera y Canción triste, resultan para nuestro crítico punto menos que indiscutibles dentro de las futuras antologías ${ }^{19}$; pertenecen ambos al libro Aires murcianos (1898), digno de elogio por la sensibilidad que muestra poseer el autor, por su realismo bien entendido y practicado, por la novedad de las imágenes, la maestría del estilo y, también, por la sencillez de sus versos, que «a mí [el crítico; repárese una vez más en lo de arma arrojadiza] me hacen mucho más efecto que las contorsiones rítmicas de otros que no sienten ni padecen... más que su vanidad, o un prurito escolástico; y escriben con cincel, como ellos dicen, o lo ven todo azul. Entre estos señoritos los hay que han llegado a adquirir una habilidad que a mí... acaba por hacerme gracia. Consiste esa diablura en escribir de manera que sus poesías, originales sin duda, parecen traducciones de versos franceses, correctas gramaticalmente, pero con el sello del galicismo en el estilo».

Nuevo ejemplo de lo que vengo llamando arma arrojadiza contra los secuaces del Modernismo lo constituye el comentario de «Clarín» a La vida inquieta (1894), libro del cordobés Manuel Reina (nacido en 1856), poeta por entonces ya conocido y prestigiado. Cada aseveración elogiosa para Reina va acompañada de alguna arremetida contra los modernistas: ocurre, por ejemplo, que «Reina es moderno, modernísimo en sus versos», pero «sin ceñirse a esta o la otra manera colegiada [de modernidad]»; ocurre que la obra de Reina se distingue por una «noble serenidad», bien lejos de «amaneramiento, de imitación servil, de exageración y afán de novedad y rareza»; ocurre que en el libro comentado «se siguen las buenas tradiciones de la musa española», pero no se le llenan «pies y manos de cascabeles para que produzca gran estrépito cuando se mueva»; ocurre, finalmente, que si el lenguaje de los poemas de $L a$ vida... es «digno de su objeto» y «correcta» la sintaxis y «propias las imágenes», nunca «se pone el estro en pugna con la lógica» ${ }^{20}$.

19 De Cansera dice Alas que «es, a mi ver, una de las más reales poesías de la lírica española en el siglo XIX»; de Canción triste piensa que «[...] siempre será una joya del arte y del sentimiento [...]» («Palique» en La vida literaria, Madrid, 20-VII1899).

20 En La Ilustración Ibérica (Barcelona, 9-II-1895). 
El caso de Salvador Rueda y su relación amistoso-literaria con Leopoldo Alas tiene especial interés. A partir de 1888, publicación del libro Sinfonía del año, Rueda (nacido en 1857) aparece como un renovador de la decaída poesía española («pudo preverse a su lectura algo de alcances inusitados» ${ }^{21}$, uno de aquellos por cuya existencia entre nosotros suspiraba «Clarín», con quien desde muy pronto en su carrera literaria estuvo relacionado Rueda. No me es posible fechar un encuentro en Asturias entre crítico y poeta, encuentro que éste recordaría así en $1925^{22}$ : «En un viaje mío a Asturias (Oviedo) para inaugurar [...] las aguas medicinales de Borines, el insigne satírico [«Clarín»] me llenó de los más calurosos elogios [...] Celebró mucho mis innovaciones y halló paralelismo entre D'Annunzio y mi insignificantísima persona de campesinillo [...]» Innovaciones las de Rueda seguidas atentamente y celebradas, sí, por «Clarín», pero llegado el innovador a ciertos extremos, su amigo y crítico va a predicarle contención y mesura, pues «será una lástima que se eche a perder» o que acabe «por despeñarse» ${ }^{23}$. Antes de que este deseo fuera formulado (a fines de 1893) hubo otros hechos que importa conocer ahora.

Quiso Rueda que Leopoldo Alas prologara Cantos de la vendimia (estamos en 1890), y a tal efecto le envió, junto a una carta-petición, el original del libro; a envío y petición respondió «Clarín» con la carta versificada que sigue ${ }^{24}$ :

PALIQUE. CORRESPONDENCIA PARTICULAR. (Imitación de Madrid Cómico.)

Sr. D. Salvador Rueda, Madrid.-Soy tan hacendoso que pierdo las cartas; las pierdo en seguida de tan bien guardadas, y jal montón anónimo vaya Vd. a buscarlas! Perdida la suya, perdidas las señas; por eso le escribo con letras de imprenta, por el Madrid Cómico, para que se sepa. ¿Que si escribo el prólogo? Sí, señor, lo escribo, porque algunos versos me gustan muchísimo; otros son medianos y los hay malitos. El conjunto puede, corrigiendo el libro, ser cosa de gusto, discreto, bonito y honrarse mi nombre con el frontispicio. Como Vd. no pide que le llame Homero, sino que le diga todo lo que

21 Tal opinaba Narciso Alonso Cortés, "Armonía y emoción en Salvador Rueda» (Cuadernos de literatura contemporánea, Madrid, 1943, n. ${ }^{\circ} 7$, p. 36).

22 En carta a Narciso Alonso Cortés fechada en Benasque a 12-III-1925 y publicada por el destinatario en su libro Artículos histórico-literarios, p. 201 (Valladolid, 1935). Por su parte, «Clarín» alude a tal viaje (en Madrid Cómico, 30-XII-1893) con estas palabras: "Vino Rueda a Asturias en cierta ocasión a inaugurar el balneario de Borines, y a los pocos días, después de un viaje de pocas horas, ya cantaba la naturaleza del Norte con el mismo color y el mismo entusiasmo con que suele cantar la de su tierra.»

Vio la luz en Madrid Cómico, n. ${ }^{\circ} 388,26-V I I-1890$. 
pienso: lo amargo, lo dulce, lo blando, lo recio, lo fuerte, lo flojo, lo malo, lo bueno, lo que está de sobra, lo que es un defecto; como con el prólogo no me comprometo a darle el diploma de poeta egregio, porque, al fin y al cabo, no soy guardasellos ni aun el Villaverde mayor de estos reinos, no quito poetas ni pongo copleros; por estas razones y otras que reservo, le haré a Vd. un prefacio en corto y ceñido, sin pinchar en hueso, si puedo impedirlo, saliendo por donde sale Lagartijo, incólume, intacto... y sin compromiso. Para pormenores que no son del caso, vuelva Vd. a escribirme, poniendo debajo la calle y el número de casa y de cuarto. ¡Ah! La Mariposa es digna de un clásico.

Desde Madrid, con fecha del día siguiente al del número 388 de Madrid Cómico (el número que insertaba la transcrita carta de Alas) y con una epístola en hexasílabos (que publiqué en otra ocasión ${ }^{25}$ ), contestó Rueda, entre agradecido y exultante - «Su ingeniosa carta/[...]/ me devuelve en parte/mi sueño perdido», o «No cambio el muchísi$m o / n i$ por un diamante/del peso de un kilo»-. Pero pasaba el tiempo sin que el poeta recibiera el prometido prólogo; por fin, tras ocho meses de espera, hubo de conformarse con el texto de una carta abierta a él dirigida por el crítico y hecha pública en el diario madrileño $L a$ Correspondencia de España, a manera de prólogo «interino» para cuya inserción en Cantos ... le autorizaba «Clarín». A vuelta de elogios y consejos, el crítico advierte al poeta que le convenía mucho no tener «pujos de reformista».

Los tenía y los siguió teniendo el malagueño hasta que «las inquinas de los retardatarios» y «las mordeduras de los colegas jóvenes» (como escribió Rubén) le llevaron a abandonar su empeño. Antes de que esto sucediera, Salvador Rueda continuó insistiendo en la innovación, estimulado desde 1892 por la amistad de Darío, que prologó su libro En tropel y le consideraba nada menos que «buen capitán de la lírica guerra,/regio cruzado del reino del arte»; y metido de lleno (Rueda) -1893 y 1894: cartas de El ritmo- en la tarea de regenerar formalmente nuestra poesía con «variedad de ritmos, variedad de estrofas, combinaciones frescas, nuevos torneados de frases, distintos modos de instrumentar lo que se siente y lo que se piensa» ${ }^{26}$.

Un texto en dos entregas, a finales de 1893 , compuesto para la se-

José María Martínez Cachero, «Salvador Rueda escribe a "Clarín”. (Una epístola en verso, inédita)» (Revista de la Universidad de Oviedo, Facultad de Letras, 1948).

26 Carta tercera sobre el ritmo (La Ilustración Ibérica, Barcelona, 2-IX-1893): fueron dirigidas a José Yxart y recogidas en volumen, 1894. 
rie de Vivos y Muertos, nunca ofrecida en volumen ${ }^{27}$, y titulado Salvador Rueda. Fragmentos de una semblanza, constituye (por lo que conozco) el último eslabón de la cadena. Al igual que en textos ya considerados, el elogio directo y el arma arrojadiza (tal vez ahora más cargada que nunca) se dan la mano. Rueda, que es poeta de «vena rica» pero frecuentemente «impura», «agrada» $\mathrm{y}$ «acierta»; posee «el don precioso del ritmo», «la viveza de la imagen» y una «imaginación plástica y poderosa», pero las malas compañías - «alguna de las epidemias de mal gusto que hoy cunden», «su obsesión en favor de ciertos poetas americanos, como Rubén Darío» o «esos amigos que le ven como un compañero en instrumentismos e impresionismos»- pueden perjudicarle gravemente.

Entrando en el espacio del Modernismo español y dando de lado menciones diversas a, vgr., Benavente (prologuista del libro Mujeres, poemas de Emilio Fernández Vahamonde ${ }^{28}$ ), Martínez Sierra (cuyos Diálogos fantásticos, colección de poemas en prosa aparecida en 1899 , reputa «Clarín» como «inaguantable prosopopeya» ${ }^{29}$ ) y Joaquín Dicenta (a quien toma por modernista y le incluye en el grupo de «ciertos pseudo-neurasténicos de las letras de relumbrón» ${ }^{30}$ ), detengámonos en los casos de Francisco Villaespesa y de Ramón del Valle Inclán.

El primero confesaba en mayo de $1900^{31}$ : «Soy su obsesión [la de «Clarín»] y me amenaza con dedicarme veinte crónicas seguidas llamándome dejenerado [sic], imbécil». Sabemos por Manuel Machado ${ }^{32}$

Era un conjunto de semblanzas, del que Leopoldo Alas escribió el prólogo (vid. Madrid Cómico, $\mathrm{n} .{ }^{\circ}$ 422) y varias piezas - sobre Ramos Carrión, Vital Aza y Salvador Rueda (entre los vivos)-; el obispo Sanz y Forés, el cardenal fray Ceferino González y sus entrañables amigos. Juan Ochoa y Tomás Tuero (entre los muertos).

Mujeres, semblanzas poéticas. Con una carta de Don Gaspar Núñez de Arce y un prólogo de Jacinto Benavente (Madrid, 1897). "Clarín» (Madrid Cómico, 5-VI1897) aconsejaba así: «No escriba el señor Benavente prólogos como el de Mujeres, y créame a.mí, que le quiero bien [...] Sepárese de ciertos señoritos que son artículos de París averiados. Benavente ha leído, tiene cierta manera original de ver el arte; pero por docilidad se deja influir por las malas compañías, y juzga, o cree juzgar, por patrón, con mal gusto ajeno.»

Madrid Cómico, 18-XI-1899.

30 En una «Revista mínima» publicada en La Publicidad (Barcelona, 26-X-1897). Acerca de la enemiga de "Clarín» a Dicenta, vid. la noticia que da Yvan Lissorgues en p. 252, nota 3 de su Clarín polttico, tomo I (Université de Toulouse-Le Mirail, 1980).

31 Carta a José Sánchez Rodríguez; se ofrece su texto en el libro de Antonio Sánchez Trigueros, Francisco Villaespesa y su primera obra poética (1897-1900). Cartas al poeta José Sánchez Rodríguez, p. 233 (Universidad de Granada, 1974).

32 Sánchez Trigueros, ob. cit., pp. 131-132. 
que al crítico le disgustó bastante un soneto de Villaespesa, Ave, Fémi$n a$, modernistamente sensual en el tono y en la expresión, y con una buscada ambigủedad que permite considerar semejantes a la protagonista y a María Magdalena; forma parte este soneto de La copa del Rey de Thule, libro de Villaespesa aparecido en 1900 y al que «Clarín» se refiere despectivamente en unos versos, métricamente a la manera del Nocturno de Silva, que figuran en su última colaboración (aparecida póstuma) en la revista barcelonesa Pluma y Lápiz $^{33}$. Libro nada nuevo La copa..., lleno de un romanticismo que queda muy remoto en el tiempo (allá por los años treinta y cinco del siglo XIX), es una muestra de la actual «escuela empecatada» del Modernismo y en sus poemas «Clarín» no percibe «algún asomo [...] por lo menos de algo fuerte $y$ espontáneo [...]»; he aquí sus versos de burla:

$\mathrm{Y}$ ahora vamos con un poeta de esos que no quieren trabas de ningún género.

Don Francisco Villaespesa, un poeta muy espeso, todo lleno de ataúdes, modernismos y murciélagos,

y que escribe versos largos, largos, largos...

y otros cortos,

como

éstos;

dio a la sombra (pues no es vulgo como otros,

y a la luz no da sus libros cadavéricos)

un tomito de poesías flatulentas

con un título de efecto:

«La copa del rey de Thule»...

Como pudo ser: «La copa del sombrero».

Es romántico cual eran los románticos

de los tiempos de Bustillo, tan remotos

que se duda

si eran tiempos.

Sólo está la diferencia en que los otros,

Larrañaga y Heriberto de Quevedo, escribían consonantes en su sitio, pues creían, limitados y modestos, que las coplas, con la rima, disimulan el nihilismo de los versos.

Los románticos de ahora, disfrazados

33 N. ${ }^{\circ}$ 36: 7-VII-1901. 
de anarquistas de la rima

$y$ aun del metro,

sólo ponen consonantes o asonantes

cuando quieren, como quieren, y ja paseo!,

porque son tan libertarios como Urales

-y está claro que no trato de ofenderlos-.

He apurado la copita hasta las heces,

y una vez con la purga en el pecho,

al autor he de decirle

sin rodeos,

que no hay nada que revele en todo el libro

ni un chispazo

del ingenio;

los lugares más comunes por doquiera:

todo el año treinta y cinco en malos versos.

Pues si hubiera yo notado algún asomo,

entre tanta extravagancia, por lo menos

de algo fuerte y espontáneo,

de una idea, de un profundo sentimiento,

perdonándole la escuela empecatada,

callaría sus errores y siniestros.

Pero todo me lo explico, contemplando

el retrato del poeta, que poseo,

pues al frente de La copa va la efigie

de este vate que es muy joven, según creo.

Un cuello de esos altos y doblados

que no dejan que se muevan los pescuezos,

cual donjon -que dirá Rubén Darío (*)

(*) y Trigo

en que llora el poeta prisionero.

¡Oh viceversas de la humana y triste raza!:

no encerramos los versitos en un metro,

y llevamos la cabeza como un palo

con más ,trabas y rigores que el retórico ovillejo.

Pero Arquímedes ya un día nos lo dijo:

«Dadme una planchadora, y dadme un camisero,

y deduzco la escuela literaria

de cualquier vate nuevo,

,de esos que antes de hacerse diputados,

y ministros, y tener riñón cubierto,

hacen versos a la moda por el último modelo

del modisto literario que esté en boga,

y en seguida se pasean satisfechos.»

Y perdone don Francisco Villaespesa, 
al que andando los años, ver espero

corregido... y aumentado, pero en prosa,

sin ser más que un ciudadano

de provecho ${ }^{34}$.

Sabido es lo difícil que le resultó a Valle Inclán ser atendido en su condición de escritor nuevo, distinto a lo habitual; la historia de su mala ventura en los concursos de cuentos de El Liberal en 1900 y $1902^{35}$ resulta muy ilustradora. Si, según Valera, al jurado del primer certamen (don Juan entre sus miembros) le retrajo «lo espeluznante, tremendo o escabroso del asunto» de Satanás, algo por el estilo había sucedido años antes a "Clarín» con el librito Epitalamio.

Luis Ruiz Contreras informa de su penosa gestación. Aquejado por entonces Valle Inclán de máximo rigor en el castigo del estilo, «al decidirse a escribir Epitalamio exageró su meticulosidad hasta el punto de permanecer horas enteras pendiente de una frase o de una palabra. Le veo aún ${ }^{36}$ en el salón espacioso de mi casa ir y venir de un extremo a otro completamente abstraído en sus ilusorias dificultades, más atento a la forma que al fondo, más al sonido que a la expresión, repetir cien veces con modulaciones distintas dos o tres palabras». Por fin se concluyó Epitalamio y salió en un tomito de 107 páginas, de las cuales únicamente 72 ofrecian texto, muy poco texto: 18 líneas por página, a 24 líneas cada página (según el recuento del mismo Ruiz Contreras). Un ejemplar, remitido por el autor, llegó a manos de «Clarín». De junio a septiembre estuvo esperando sobre la mesa del crítico a que éste le concediera su atención; el número de Madrid Cómico correspondiente al día 25-IX-1897 insertaba un «palique» dedicado al enjuiciamiento del librito.

Reconoce Alas en su autor algunas aprovechables cualidades - «se ve que tiene imaginación, es capaz de llegar a tener estilo, no es un cualquiera»-, pero ¡cuán largamente contrapesadas por otras cualidades censurables! Así tenemos: ofensas a la gramática que «Clarín», tan puntilloso a este respecto, denuncia - «por donde quiera que se abre el Epitalamio hay algo en cueros vivos y una contorsión gramatical o re-

34 Villaespesa dedicó a Leopoldo Alas el soneto $A l$ volver a la aldea (fechado en Sierra de la Alpujarra, agosto 1903), del libro Rapsodias (Madrid, 1905).

35

Melchor Fernández Almagro, Vida y literatura de Valle-Inclán, pp. 70-72 y p. 97. (Madrid, Editora Nacional, 1943).

36 Luis Ruiz Contreras, Memorias de un desmemoriado, pp. 195-196. (Madrid, Aguilar, 1945). 
tórica. "Amaba con el culto olímpico de las diosas desnudas". Ni se ama con el culto ni las diosas tributan culto, sino que lo reciben, ni hay diosas desnudas..., así, por antonomasia»-; revuelta mezcla de paganismo, sensualismo y cristianismo - «Augusta, la desnudísima y sin vergüenza Augusta, le pone a su esposo unos cuernos... olímpicos. Y su amante la llama madona [...] Yo no diré que los debían llevar a ustedes presos, por decir esas cosas, pero sí que, por lo menos, merecen ustedes que les anden buscando. "Alma extraña, que si rezase buscaría a Cristo en el Olimpo y a Júpiter en el Cielo"'. Esas son sencillamente... locuras, incongruencias, Sr. Valle Inclán»-; perversidad del asunto - «en cuanto al cinismo repugnante que es el fondo de Epitalamio, no crea el autor que ha encontrado ningún estercolero nuevo [...]».

Con todo, nuestro crítico moralista ${ }^{37}$ reconoce en Valle Inclán, que es hoy por hoy solamente «un muchacho extraviado» por las malas lecturas y las malas compañías literarias, y de ello debe arrepentirse, capacidad para «trabajar en la verdadera viña» ${ }^{38}$.

\section{Final}

No son únicamente los textos relativos a ciertos libros y escritores españoles los que prueban la actitud anti-modernista del crítico «Clarín» ${ }^{39}$; junto a ellos hay otros más generales (unas pocas líneas, de ordinario) que corroboran semejante toma de partido. Tal sucede, vgr., cuando Leopoldo Alas deja de ser, a petición propia, el director

37 En el artículo «Mala maña» (La vida literaria, Madrid, 11-II-1899) insiste «Clarín» en denunciar el erotismo de algunos escritores jóvenes: «Parece mentira, pero hay no pocos supuestos literatos jovenes que ofrecen a la admiración de sus contemporáneos una especie de lirismo... bueno para sementales. ¿Que son ustedes muy lúbricos? Más lo fue Horacio, un viejo verde que pocos de ustedes han leído. No, no es una garantía de mérito artístico la ostentación de una juventud lasciva que no quiere ser casta... ni cauta.»

La historia completa de la relación Valle Inclán-«Clarín» la ha ofrecido Dionisio Gamallo Fierros en el apartado «Tres cartas de V.-I. a Clarín y una de éste, abierta, a don Ramón (1895-1897)» de su artículo "Aportaciones al estudio de ValleInclán» (Revista de Occidente, Madrid, núms. 44-45, XI-XII-1966, pp. 347-361).

39. No me he propuesto tratair aquí de la actitud de «Clarín» ante los modernistas hispano-americanos, idéntica a la mantenida frente a los españoles; si Villaespesa fue entre estos últimos el más perseguido por nuestro crítico, Rubén Dario lo fue entre aquéllos. "Las observaciones y comentarios de Alas con referencias a R. D. están cargados de insinuaciones y reticencias malévolas. El noble y abierto luchador que fue "Clarín", se rebaja y ciega», según Fernando Ibarra («Clarín y Rubén Dario: Historia de una incomprensión», Hispanic Review, XLI, 1973, n. ${ }^{\circ}$ 3, pp. 524-540). 
«ausente» (en Oviedo) del semanario madrileño Madrid Cómico - septiembre de 1898- y explica la inclusión en sus páginas de escritos modernistas - «cuando vean Vdes. cosillas afrancesadas melancólicamente verdes (verdi-negras, pues lo melancólico es negro), desnudeces alicaídas, secciones extravagantes y otros artículos de París, háganme el favor de pensar que eso yo lo tolero, pero no lo apadrino. Pero Madrid Cómico es como el sol, sale para todos ${ }^{40}{ }^{4}$; o en el breve insulto generalizado de $1900^{41}$ : «[...] esos nelumbis y crisantemos poéticos, jóvenes nenúfares y memo-liliales [...]». No es que se haya convertido en censor sistemático de la juventud literaria; en los jóvenes, como en los mayores, combate Alas «la pose, la servil imitación, el descaro y la falta de respeto ${ }^{42}$.

¿Cuál pudo ser la razón sustancial del anti-Modernismo «clariniano»? Quedan apuntados algunos de sus disentimientos - por ejemplo: desilusión y alarma ante la obra realizada por los sedicentes innovadores, peligro galicista y consiguiente disolución de lo nuestro, erotismo exacerbado- con la llamada nueva estética, pero aquello que los unifica y les otorga un sentido relevante es, quizá, el hecho de que a «Clarín» le disgustaba cualquier tipo de mero juego literario, de virtuosismo sin apoyo en lo serio y trascendental. Más que de un enfrentamiento entre generaciones - «gente vieja» contra «gente nueva», y algo hubo de esto-, se trataba de una inadecuación o falta de correspondencia entre la insoslayable realidad literaria del Modernismo y el ánimo de Leopoldo Alas $^{43}$, cada día más profundamente inmerso en otras realidades. Recuérdense a este respecto: su adscripción a la cátedra de «Derecho Natural» (o «Filosofía del Derecho») y un muy gustoso y mantenido asentamiento en esta materia o disciplina; un creciente espiritualismo que debía mucho a Giner de los Ríos pero también a Tolstoi y a Renan $\mathrm{y}$, asimismo, a la creencia religiosa que presidió su infancia y adolescencia; el peso del ambiente universitario ovetense (Facultad de Derecho) en los años finales de siglo, cuya muestra más cabal fue la obra de Extensión Universitaria a partir de 1898; el mal derrotero seguido por la política y por las armas españolas en Cuba; puede que alguna otra cosa más. Por eso «Clarín» atiende un tanto a regañadientes la petición de un prólogo para Almas y cerebros (libro de Gómez Carrillo), y en lo

\footnotetext{
40 Madrid Cómico, 3-XII-1898.

41 De un «palique» en Madrid Cómico.

42 «Palique» en Heraldo de Madrid, 9-X-1897.

43 Coincido en esta conclusión con la hipótesis enunciada por Antonio RamosGascón, «Clarín». Obra olvidada. Artículos de crítica», p. 23. (Maidrid, Júcar, 1973).
} 
que escribe, advierte por dos veces que «el estado actual de mi ánimo (de mi alma)» o «mis ideas, mis gustos, mis preferencias presentes en estudios, meditaciones y lecturas» no resultaban oportunos «para tratar con el entusiasmo que sería del caso los asuntos [de este libro]», casi un prontuario de decadentismo parisiense ${ }^{44}$.

44 Almas y cerebros. Historias sentimentales, intimidades parisienses, etc. (París, Garnier, 1898). Las palabras que entrecomillo pertenecen a las pp. VII, VIII y IX. 